\title{
THE EFFECT OF LIVESTOCK GRAZING ON THE RAINBOW GRASSHOPPER: POPULATION DIFFERENCES AND ECOLOGICAL CORRELATES
}

\author{
Sandra J. DeBano ${ }^{1,2}$
}

\begin{abstract}
This study examined the effect of livestock grazing on a common herbivore in semiarid grasslands of the Southwest: the rainbow grasshopper, Dactylotum variegatum. Population attributes and key environmental variables were compared between sites on active cattle ranches and sites on a 3160-ha ungrazed sanctuary. Although density of $D$. variegatum nymphs did not differ significantly between grazed and ungrazed sites, adult density was significantly lower on grazed sites, and sex ratios differed between grazed and ungrazed sites over time. Grazed sites had higher percentages of bare ground and fewer Baccharis pteronioides, a common shrub. However, only bare ground was highly correlated with adult $D$. variegatum density; lower adult densities were associated with more bare ground. At a smaller scale, D. variegatum tended to be more abundant in areas with B. pteronioides on grazed sites and less abundant in areas on ungrazed sites. This study suggests that cattle grazing influences ecological variables important in determining density, sex ratio, and spatial distribution of $D$. variegatum at both large and small spatial scales.
\end{abstract}

Key words: livestock grazing, Dactylotum variegatum, grasshopper, adult density, nymphal density, sex ratio, spatial distribution, Baccharis pteronioides, bare ground, scale, semiarid grasslands, Arizona.

One major human-caused disturbance in the southwestern United States is livestock grazing. Livestock grazing began in the 1500s with the Spaniards' introduction of cattle and sheep (Hastings and Turner 1965), and large scale cattle ranching in the Southwest was common by the 1870s (Bahre 1991). Livestock grazing continues as a multimillion dollar industry and has been suggested as "the most widespread influence on native ecosystems in western North America" (Fleischner 1994).

Numerous studies have documented the effects of livestock grazing in arid and semiarid grasslands of the southwestern United States on a variety of plants and vertebrate animals (reviewed by Fleischner 1994 and Jones 2000). However, studies on the effects of livestock grazing on invertebrates in these areas are less numerous (Pfadt 1982, Jepson-Innes and Bock 1989, DeBano 1995) despite the fact that grassland invertebrates comprise an overwhelming proportion of animal biomass and biodiversity, form a major component of terrestrial food webs, and play pivotal roles in ecosystem functions (Wilson 1987, Kellert 1993, Whitford et al. 1995, Coleman and Hendrix 2000).
In many grasslands one of the most important groups of invertebrates is grasshoppers; they are common and dominant herbivores in these systems (Samways 1994). Changes in grasshopper populations can be among the first indications of human-caused disturbances, including cattle grazing. Outside the Southwest, livestock grazing has both negative and positive impacts on grasshopper populations, depending on the specific habitat requirements of the species (e.g., Holmes et al. 1979, Capinera and Sechrist 1982, Quinn and Walgenbach 1990, Miller and Onsager 1991, Welch et al. 1991, Fielding and Brusven 1995). Changes in grasshopper populations brought about by human disturbance can have significant repercussions for plant and animal communities. For example, Belovsky and Slade (2000) showed that increased density of grasshoppers accelerated nutrient cycling and increased plant production in Montana, and Bock et al. (1992) found that grasshoppers were an important food source for birds in Arizona. These studies reveal the importance of grasshoppers in structuring grassland systems.

The purpose of this study was to examine how livestock grazing affects a common grasshopper

\footnotetext{
${ }^{1}$ Department of Entomology, University of Kentucky, Lexington, Kentucky.

2Present address: Department of Fisheries and Wildlife, Oregon State University, Hermiston Agricultural Research and Extension Center, Box 105, Hermiston, OR 97838
} 
species found in semiarid grasslands of the Southwest: the rainbow grasshopper, Dactylotum variegatum. Dactylotum variegatum is a brilliantly colored, flightless, North American melanopline (Whitman 1990) believed to be aposematic, sequestering toxins from composites of the genus Baccharis (Miyakado et al. 1974) on which $D$. variegatum nymphs preferentially feed (Parker 1982). Feeding experiments with birds and small mammals (Isley 1938, Roberts 1947, Neal et al. 1994), as well as a study showing that density of $D$. variegatum is unresponsive to changes in predation pressure from birds (Bock et al. 1992), support this hypothesis. Adults of D. variegatum are polyphagous, and the abundance of the species and its probable role as a major herbivore (Jepson 1985, Bock and Bock 1991, Neal et al. 1994, DeBano 1995) suggest that it is an important component of arid grassland communities. Except for an unreplicated study in southeastern Arizona, which showed that overall density of $D$. variegatum was lower at 1 grazed site than at 1 ungrazed site during 2 summers (Jepson 1985), no work has examined how livestock grazing affects population attributes of D. variegatum (e.g., adult and nymphal densities, sex ratio, and spatial distribution with respect to the nymphal food plant).

If $D$. variegatum experiences different selection pressures in grazed and ungrazed environments, examining nymphal and adult density separately should provide clues about the stage at which this selection is acting. Like other insects, mortality rates at early stages can be substantial, and changes in population sizes of grasshoppers are often due to environmental effects on early stages, especially the nymphal stage (Chapman and Page 1979, Farrow 1982a, $1982 \mathrm{~b})$. Thus, if selection is stronger in grazed areas and acts at early instars, densities of both $D$. variegatum nymphs and adults are predicted to be lower in grazed environments compared to ungrazed ones. However, if selection acts primarily at late instar or adult stages, then only adult density should differ between the 2 types of habitats.

Sex ratio is another population attribute that may be affected by environmental change associated with livestock grazing. Differences in adult sex ratio are expected if males and females show differential mortality in response to environmental conditions, especially in species such as $D$. variegatum that display strong sexual dimorphism (Clutton-Brock et al. 1985, Weatherhead and Teather 1991). If, because of their larger size, $D$. variegatum females are more dependent on abundant food sources (DeBano 1997) and the production of energetically costly egg masses, then they might experience higher mortality earlier in the season in grazed areas than in ungrazed areas.

Ultimately variation in environmental variables drives observed patterns in population attributes. Livestock grazing alters various environmental factors that should impact grasshoppers and other invertebrates including vegetation characteristics, soil compactness, and microhabitat temperature and humidity (Whitford et al. 1995, Loftin et al. 2000). The spatial scale at which these variables operate is unclear, because this has been given little consideration in studies of human disturbance on grassland systems. However, understanding the spatial scale at which processes operate is important to fully understanding human impacts on grassland ecosystems (Levin 1992, Wiens 2001).

The objectives of this study were to (1) examine how livestock grazing affects population attributes of $D$. variegatum including adult density, nymphal density, and sex ratio; (2) determine how several key ecological variables vary with population attributes of $D$. variegatum at a large scale; and (3) determine smaller scale spatial distribution of individuals with respect to a potentially important nymphal food source, Baccharis pteronioides. The results of this study address the importance of livestock grazing as a disturbance to this common insect and suggest mechanisms that might be responsible for the effect of grazing at different spatial scales.

\section{STUdy SiTe}

I conducted this study at National Audubon Society's Appleton-Whittell Research Ranch (hereafter referred to as the "Research Ranch") located on the Sonoita Plain, Santa Cruz County, Arizona. The Research Ranch is a 3160-ha sanctuary of private lands and public lands administered by the USDA Forest Service and the USDI Bureau of Land Management. Livestock grazing was discontinued on the Research Ranch in 1968, but the property is currently surrounded by active cattle ranches. Four $30 \times$ 30 -m ungrazed sites on the Research Ranch were paired with four $30 \times 30$-m grazed sites 
on adjacent active cattle ranches. Sites were paired based on similarities in elevation, topography, soil type, and vegetation. Sites within a pair were separated by $1.0-1.8 \mathrm{~km}$, and pairs were separated by an average of $2.6 \mathrm{~km}$. Elevations of the sites ranged from $1463 \mathrm{~m}$ to 1524 $\mathrm{m}$, with the largest difference between a pair of sites being $15 \mathrm{~m}$. All soils were gravely loam of the White House Series, and topography of all sites was flat. Two of the grazed sites were managed with holistic resource management practices (Savory 1999) that use high density stocking rates ( 1 animal unit per 6 ha) with short duration rotation. The other 2 grazed sites were managed with traditional grazing practices, using lower stocking rates $(\sim 1$ animal unit per $39 \mathrm{ha}$ ) with season-long grazing.

Because of its size and the length of time it has been ungrazed, the Research Ranch provides one of the greatest contrasts between grazed and ungrazed grasslands in the southwestern United States and represents the logical starting point for investigations into the effects of livestock grazing in the area. Although the 4 ungrazed sites are all located on the Research Ranch, there is no reason to believe that their location reflects any commonality, other than the cessation of livestock grazing in 1967, for the following reasons: (1) the sites are widely separated, and (2) the only management practice conducted on the Research Ranch sites between 1967 and this study was the removal of livestock. In other words, no specific management practices, other than the removal of livestock, have taken place on the Research Ranch that would make it different from any other area in the region where livestock had been removed. However, to avoid pseudoreplication (Hurlbert 1984), results of this study are generalized only to the grasslands of the Research Ranch and the surrounding cattle ranches.

\section{Methods}

To determine if adult density, nymphal density, or sex ratios of $D$. variegatum differed between grazed and ungrazed sites, I sampled each site 4 times in 1994 (8-13 July, 14-17 July, 21-24 July, and 5-8 August). Sampling was timed to span the period when adults begin to emerge to when populations decline. Unlike many other grasshopper species in southeastern
Arizona, D. variegatum emerges and disappears fairly early in the season (Lee 1991). Eggs of $D$. variegatum begin to hatch in spring (late April or May) from overwintering eggs laid the previous summer; adults begin to appear in midsummer (typically July) with the onset of summer rains; and populations generally decline towards the end of August (Lee 1991). Each sampling bout lasted 4 days with 1 pair of sites being sampled each day. Adult and nymphal densities at each site were sampled using a wire ring method to delineate subsample boundaries (Onsager and Henry 1978), a method effective for sampling grasshoppers in this habitat (Jepson-Innes and Bock 1989, Bock and Bock 1991). At each site I randomly placed 54 rings, each marking an area of $1.0 \mathrm{~m}^{2}$, and left them overnight. The next morning I counted all $D$. variegatum nymphs and male and female adults in each ring.

Three environmental variables were also measured in July 1994. I calculated percent bare ground at each of the 8 sites by visually estimating to the nearest $5 \%$ in each of the 1$\mathrm{m}^{2}$ wire rings used to sample $D$. variegatum density. I also counted the number of B. pteronioides at each site and measured the size of each shrub by measuring maximum volume (i.e., the product of the maximum height, maximum width, and depth perpendicular to the maximum width) for either all B. pteronioides at each site or a random subsample of 44 shrubs for the 2 sites which had more than 44 shrubs.

To determine whether $D$. variegatum was preferentially associated with $B$. pteronioides within grazed and ungrazed sites, I conducted stratified sampling in 1995 (Southwood 1978). Areas with and without B. pteronioides were sampled twice at each site (5-19 July and 25 September-11 October). At each site, fifty-four $1.0-\mathrm{m}^{2}$ areas were subsampled using the ring method described above. At sites with less than 27 B. pteronioides shrubs, all areas with $B$. pteronioides were subsampled, and the remaining rings were used to subsample areas without B. pteronioides; for sites with more than 27 B. pteronioides, a random subsample of 27 areas of each type of habitat was taken. Subsamples for areas with B. pteronioides contained only 1 shrub per ring.

Data were tested for normality using Lillefors test (SYSTAT 1997) and transformed, if necessary, to meet assumptions of parametric 
TABLE 1. Results of repeated measures ANOVA for the effect of livestock grazing on adult and nymphal densities and sex ratio (proportion of males) of $D$. variegatum at 4 grazed and 4 ungrazed sites during 4 sampling periods in 1994 . The interaction effect between time and grazing was the first term examined (von Ende 1993); if insignificant, time and grazing were considered independently.

\begin{tabular}{|c|c|c|c|c|c|c|}
\hline \multirow[b]{2}{*}{ Population attribute } & \multicolumn{2}{|c|}{ Grazing treatment $\times$ Time } & \multicolumn{2}{|c|}{ Grazing treatment } & \multicolumn{2}{|c|}{ Time } \\
\hline & $F$ & $P$ & $F$ & $P$ & $F$ & $P$ \\
\hline Adult density & 3.0 & 0.14 & 14.4 & 0.009 & 12.2 & 0.01 \\
\hline Nymphal density & 2.9 & 0.07 & 3.85 & 0.10 & 2.2 & 0.12 \\
\hline Sex ratio & 19.2 & 0.05 & 1.2 & 0.39 & 19.0 & 0.05 \\
\hline
\end{tabular}

statistical analyses. If data could not be transformed to satisfy assumptions, nonparametric techniques were used. Means are reported \pm 1 standard error.

Square-root-transformed adult density, logtransformed nymphal density, and sex ratio (proportion of males) were analyzed with repeated measures ANOVA. Data on percent bare ground and maximum volume of $B$. pteronioides were analyzed with ANOVA blocked by paired sites. Shrub abundance at ungrazed and grazed sites was compared using a MannWhitney U test. To examine the association of D. variegatum population characteristics with environmental variables, I compared each environmental variable at the 8 sites in 1994 with the corresponding average of adult density, nymphal density, and sex ratio of $D$. variegatum using Pearson's correlation coefficient. Data from July and September 1995 on the spatial distribution of $D$. variegatum with respect to $B$. pteronioides were combined and analyzed using Wilcoxon's signed-ranks test for grazed and ungrazed sites separately.

\section{RESUlTS}

There was no significant interaction of grazing treatment and time $(\alpha=0.05$ for all analyses) on the density of adult $D$. variegatum in 1994, indicating that the effects of grazing treatment and time were independent (Table 1). However, both main effects were statistically significant when examined separately, with a higher density of adult $D$. variegatum at ungrazed sites than grazed sites and decreased density through the sampling period (Table 1, Fig. 1a).

Although the density of nymphs at grazed sites was low throughout the sampling period while the density of nymphs at ungrazed sites
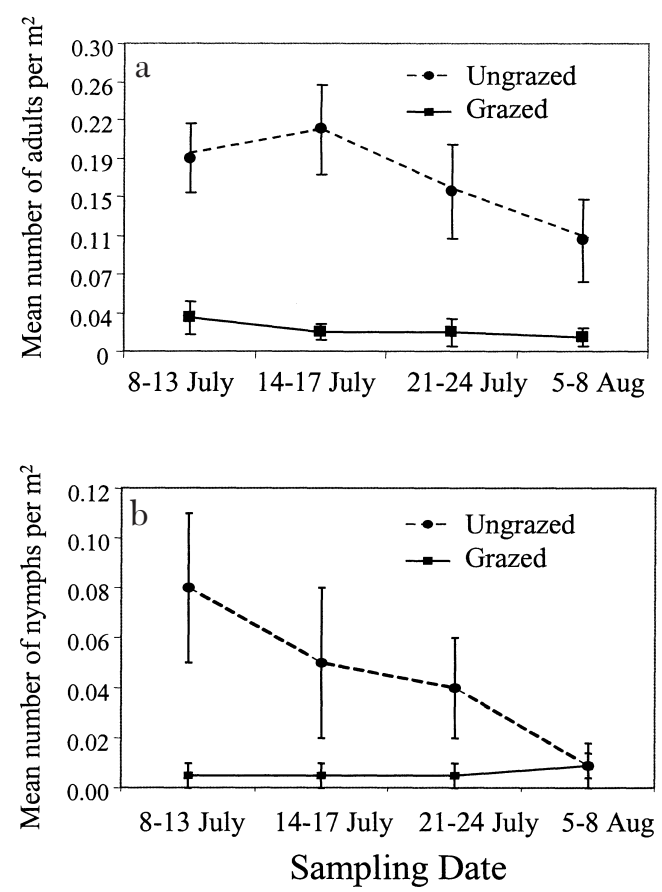

Fig. 1. Mean density of D. variegatum at grazed and ungrazed sites during 4 sampling periods in 1994 for (a) adults and (b) nymphs. Note that scale of the y-axis differs between graphs.

decreased steadily throughout the same period (Fig. 1b), the interaction of grazing treatment and time was not statistically significant (Table 1). The separate effects of grazing and time on nymphal density were also not statistically significant (Table 1).

There was a significant interaction between grazing treatment and time on sex ratio of $D$. variegatum (Table 1), indicating that patterns in sex ratio varied between grazed and ungrazed sites through time. Sex ratios at ungrazed sites started out male-biased and gradually became 
TABLE 2. Correlations of population characteristics of $D$. variegatum with environmental variables using Pearson's correlation coefficient at 8 sites (4 grazed and 4 ungrazed sites) in 1994.

\begin{tabular}{lccr}
\hline & Adult density & Nymphal density & Sex ratio \\
\hline \% bare ground & $-0.84^{*}$ & -0.69 & 0.52 \\
Number of B. pteronioides & 0.44 & -0.03 & -0.18 \\
Volume of B. pteronioides & 0.36 & 0.29 & 0.24 \\
\hline
\end{tabular}

${ }^{*} P<0.01$

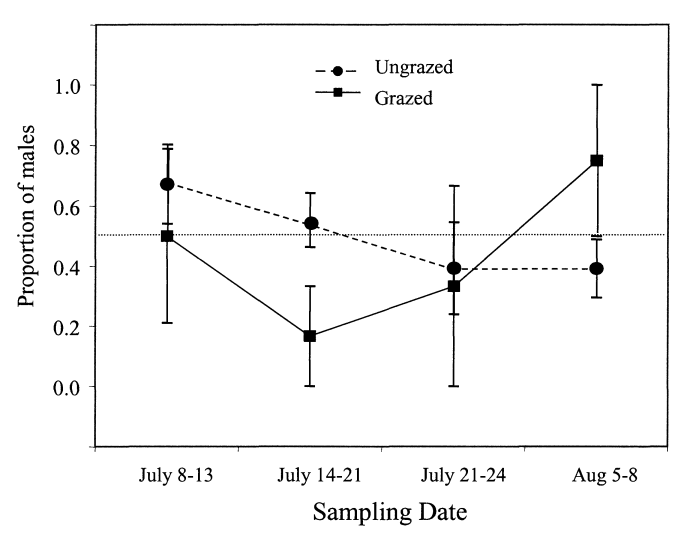

Fig. 2. Proportion of D. variegatum males at grazed and ungrazed sites during 4 sampling periods in 1994. A value of 0.5 for the proportion of males corresponds to a $1: 1$ sex ratio and is indicated by a dotted line.

more female-biased through most of the sampling period, while the sex ratio at grazed sites started out roughly equal, became more femalebiased during the middle of the sampling period, and more male-biased at the end of the sampling period (Fig. 2).

Two of the 3 environmental variables differed significantly between grazed and ungrazed sites. Mean percent bare ground was significantly less on ungrazed sites $(42.3 \% \pm 1.80 \%)$ than grazed sites $(69.2 \% \pm 3.31 \% ; F=9.5, P=$ 0.03 ), while mean abundance of $B$. pteronioides, measured as the number of individual shrubs per site, was significantly greater on ungrazed sites $(120 \pm 44.9)$ than grazed sites $(11 \pm 3.3 ; \mathrm{U}=0, P=0.02)$. However, the average maximum volume of individual $B$. pteronioides shrubs did not differ significantly between grazed $(7.8 \pm 0.62 \mathrm{~L})$ and ungrazed sites $(5.7 \pm 0.62 \mathrm{~L} ; F=0.45, P=0.50)$.

Only 1 environmental variable was significantly correlated with any of the population characteristics of $D$. variegatum measured (Table 2). Percent bare ground was highly neg- atively correlated with adult density. Percent bare ground was also negatively correlated with mean nymphal density, but the relationship was not statistically significant.

Data from stratified sampling in 1995 revealed that $D$. variegatum tended to show different spatial distributions at ungrazed and grazed sites relative to the shrub $B$. pteronioides. Within grazed sites mean density of $D$. variegatum in areas with $B$. pteronioides was 10 -fold higher than areas without B. pteronioides, although this difference was not statistically significant $(Z=-1.86, P=0.06$; Fig. 3a). In contrast $D$. variegatum showed no obvious pattern within ungrazed sites in relation to $B$. pteronioides $(Z=-0.13, P=0.89$; Fig. 3b).

\section{Discussion}

This work shows that livestock grazing on this Arizona plain has a strong negative effect on adult density of $D$. variegatum, an important native herbivore in these grassland systems. The lack of a significant grazing $\times$ time interaction effect on adult density suggests that selection caused by environmental perturbation associated with livestock has already operated by the time grasshoppers reach the adult stage. Less clear is whether selection acts largely on egg or early nymphal stages, rather than late nymphal stages. Although the effect of grazing on the density of nymphs was not statistically significant at $\alpha=0.05$, nymphal density of $D$. variegatum was uniformly low at grazed sites throughout the season in contrast to much higher nymphal density at ungrazed sites early in the season. This suggests that selection may, in fact, be acting at fairly early stages. Although my observations might also result from fecundity differences associated with the 2 environmental types, no significant differences in variables associated with fecundity (number of ovarioles, eggs per ovariole, or reabsorbed eggs) were evident in females 


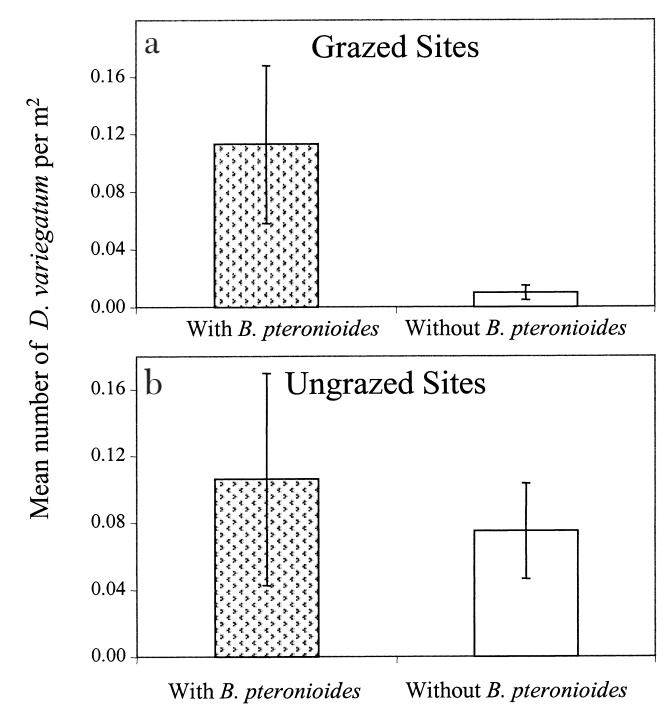

Fig. 3. Density of D. variegatum in areas with and without B. pteronioides in 1995 for (a) grazed sites and (b) ungrazed sites.

collected from grazed and ungrazed sites during the same time period (DeBano 1997).

This study also examined differences in sex ratio between grazed and ungrazed sites. Differences are expected if males and females show differential mortality to changes in ecological factors associated with livestock grazing. Patterns of change in sex ratio differed significantly through time, with sex ratio becoming more male-biased late in the season at grazed sites and more female-biased at ungrazed sites. However, contrary to predictions, sex ratio was more female-biased at grazed sites early in the season, suggesting that if grazed environments are particularly harsh for females, associated effects on mortality do not occur until late in the season.

Two environmental variables, percent bare ground and number of $B$. pteronioides, differed significantly between grazed and ungrazed sites. Grazed sites had significantly more bare ground and fewer B. pteronioides than ungrazed sites. However, only bare ground was significantly correlated with any of the population characteristics of $D$. variegatum measured in this study. Specifically, bare ground was negatively correlated with adult density at the 8 sites, and showed a similar, nonsignificant relationship with nymphal density. Bare ground might have negative impacts on $D$. variegatum for a variety of reasons. Bare ground is associated with higher temperatures and lower relative humidity, potentially making thermoregulation in grazed areas more difficult. A previous study of $D$. variegatum showed that this species is sensitive to temperature changes and alters its diurnal movement to regulate body temperature (Parker 1982). Lack of vegetation associated with bare ground might also be driving differences in $D$. variegatum density between grazed and ungrazed sites. Less vegetation means reduced availability of food and shelter. However, polyphagous $D$. variegatum adults should be more buffered from the effects of food availability than specialists (Redfearn and Pimm 1988) and may be less limited by food than by shelter.

The lack of correlation of nymphal density with either the number or maximum volume of B. pteronioides was surprising given that nymphs of $D$. variegatum are suspected to specialize on the plant (Parker 1982). One potential reason for the lack of relationship is that the shrub, although potentially important to the small-scale distribution of $D$. variegatum in general, does not play a role in its largescale distribution. The shrub was present at all sites, and perhaps even the small number of shrubs found at grazed sites provided sufficient resources for nymphs.

In contrast to these large-scale effects, $B$. pteronioides may play an important role at a smaller scale within a habitat. Within grazed sites, density of $D$. variegatum in 1995 was much higher in areas with $B$. pteronioides than areas without. Although this difference was not significant at $\alpha=0.05$, the magnitude of the difference and the associated low probability value $(P=0.06)$ differs sharply with the pattern observed at ungrazed sites. Within ungrazed sites, mean density of $D$. variegatum in areas with B. pteronioides was only slightly higher than areas without $B$. pteronioides, and the $P$-value was high $(P=0.89)$. These data suggest that $D$. variegatum may modify its behavior in response to different selection pressures in the 2 types of environments. The value of $B$. pteronioides to $D$. variegatum as food and as shelter from extreme microclimates might be enhanced in grazed environments. In grazed areas other sources of food for herbivorous insects are greatly reduced, as evidenced by the high amount of bare ground, 
and so the relative value of remaining vegetation is higher. In addition, higher temperatures and lower relative humidity of microhabitats on bare soil surfaces should be moderated by the shading of vegetation. Thus, the need for grasshoppers to use existing vegetation as roosts to escape unfavorable microclimates is probably more important in grazed areas than ungrazed areas. Shrubs might be preferred over grass canopy in these areas because shrub canopy generally provides more moderation of microclimatic conditions than grass canopy (Whitford et al. 1995).

In addition to providing information on the distribution of $D$. variegatum relative to $B$. pteronioides, the data collected in 1995 are consistent with the previous year's data showing that ungrazed sites had a much higher overall average density of $D$. variegatum than grazed sites. Although densities of $D$. variegatum in areas with $B$. pteronioides were roughly equivalent in grazed and ungrazed sites in 1995 (Fig. 3), it is important to note that this habitat type was much more abundant in ungrazed areas; on average, ungrazed sites had $>10$ times more B. pteronioides than grazed sites. In addition, the average number of $D$. variegatum in areas without B. pteronioides is over 7 times greater on ungrazed grasslands than on grazed grasslands. Thus, like the previous year, overall $D$. variegatum densities were still much higher in ungrazed grasslands.

In summary, this study shows that livestock grazing heavily impacts populations of a common herbivorous invertebrate by influencing adult density and altering sex ratio through time. The results also highlight the importance of considering spatial scale when examining how disturbance affects populations and how environmental variables interact across these scales. Environmental variables that may play a role in determining distribution of individuals within a habitat, such as B. pteronioides distribution, might not be important at larger scales. Other factors, like percent bare ground, might be important in determining overall density at larger spatial scales and might enhance the effect of other environmental variables at smaller scales.

\section{ACKNOWLEDGMENTS}

I thank T. Klapwyk and K. Cooper for their help in the field; A. Moore for his guidance and support; the Jelks, Pyeatt, and Brophy families for allowing me to work on their ranches; and D. Wooster for thoughtful comments on the manuscript. This work was partially funded by grants from the Appleton-Whittell Research Ranch Foundation and by the EPScoR program through the Center for Evolutionary Ecology and Behavior at the University of Kentucky.

\section{Literature Cited}

Bahre, C.J. 1991. A legacy of change. University of Arizona Press, Tucson.

Belovsky, G.E., AND J.B. Slade. 2000. Insect herbivory accelerates nutrient cycling and increases plant production. Proceedings of the National Academy of Science 97:14412-14417.

Bock, C.E., AND J.H. Bock. 1991. Response of grasshoppers (Orthoptera: Acrididae) to wildfire in a southeastern Arizona grassland. American Midland Naturalist 125:162-167.

Bock, C.E., J.H. BoCK, AND M.C. GRANT. 1992. Effects of bird predation on grasshopper densities in an Arizona grassland. Ecology 73:1706-1717.

Capinera, J.L., and T.S. SEChrist. 1982. Grasshopper (Acrididae) host plant associations: response of grasshopper populations to cattle grazing intensity. Canadian Entomologist 114:1055-1062.

Chapman, R.F., and W.W. Page. 1979. Factors affecting the mortality of the grasshopper, Zonoildcerus variegatus, in southern Nigeria. Journal of Animal Ecology 48:271-288.

Clutton-Brock, T.H., S.D. Albon, and F.E. Guinness. 1985. Parental investment and sex differences in juvenile mortality in birds and mammals. Nature 313: 131-133.

Coleman, D.C., AND P.F. HendRIX, EDITORS. 2000. Invertebrates as webmasters in ecosystems. CABI Publishing, New York.

DeBAnO, S.J. 1995. The effects of grazing history on insect communities of a semiarid grassland. Pages 612-615 in L.F. DeBano, P.F. Ffolliott, A. Ortega-Rubio, G.J. Gottfried, R.H. Hamre, and C.B. Edminster, editors, Biodiversity and management of the Madrean Archipelago: the sky islands of southwestern United States and northwestern Mexico. USDA Forest Service, General Technical Report RM-264. Fort Collins, CO.

DeBAnO, S.J. 1997. The effects of ecological disturbance caused by livestock grazing on the ecology, morphology, physiology, and behavior of the rainbow grasshopper, Dactylotum variegatum. Doctoral dissertation, University of Kentucky, Lexington.

Farrow, R.A. 1982a. Population dynamics of the Australian plague locust, Chortoicetes terminifera (Walker), in central New South Wales. II. Factors influencing natality and survival. Australian Journal of Zoology 30:199-222.

1982b. Population dynamics of the Australian plague locust, Chortoicetes terminifera (Walker), in central New South Wales. III. Analysis of population processes. Australian Journal of Zoology 30:569-579.

Fielding, D.J., AND M.A. Brusven. 1995. Grasshopper densities on grazed and ungrazed rangeland under 
drought conditions in southern Idaho. Great Basin Naturalist 55:352-358.

Fleischner, T.L. 1994. Ecological costs of livestock grazing in western North America. Conservation Biology 8:629-644.

Hastings, J.R., and R.M. Turner. 1965. The changing mile: an ecological study of vegetation change with time in the lower mile of an arid and semiarid region. University of Arizona Press, Tucson.

Holmes, N.D., D.S. Smith, AND A. Johnston. 1979. Effect of grazing by cattle on the abundance of grasshoppers on fescue grassland. Journal of Range Management 32:310-311.

Hurlbert, S.H. 1984. Pseudoreplication and the design of ecological experiments. Ecological Monographs 54: 187-211.

ISLEY, F.B. 1938. Survival value of acridian protective coloration. Ecology 19:370-389.

JEPSON, K.A. 1985. Response of grasshoppers to changes in vegetation structure and availability: a comparison of grazed and ungrazed sites in southeastern Arizona. Masters thesis, University of Colorado, Boulder.

JEPSON-INNES, K., AND C.E. BoCK. 1989. Response of grasshoppers (Orthoptera: Acrididae) to livestock grazing in southeastern Arizona: differences between seasons and subfamilies. Oecologia 78:430-431.

Jones, A. 2000. Effects of cattle grazing on North American arid ecosystems: a quantitative review. Western North American Naturalist 60:155-164.

Kellert, S.R. 1993. Values and perceptions of invertebrates. Conservation Biology 7:845-855.

LEE, J.C. 1991. Learning and nutritional aspects of individual polyphagy in the insect herbivores, Schistocerca americana, Dactylotum variegatum, and Trichoplusia ni. Doctoral dissertation, University of California, Berkeley.

LEvin, S.A. 1992. The problem of pattern and scale in ecology. Ecology 73:1943-1967.

Loftin, S.R., C.E. Bock, J.H. Bock, and S.L. Brantley. 2000. Desert grasslands. Pages 53-96 in R. Jemison and C. Raish, editors, Livestock management in the American Southwest: ecology, society, and economics. Elsevier, New York.

Miller, R.H., and J.A. Onsager. 1991. Grasshopper (Orthoptera: Acrididae) and plant relationships under different grazing intensities. Environmental Entomology 20:807-814.

Miyakado, M., N. Ohno, H. Yoshioka, T.J. Mabry, and T. WhifFin. 1974. Gymnospermin: a new ladan triol from Gymnosperma glutinosa. Phytochemistry 13:189-190.

Neal, P.R., M.R. Stromberg, and K.A. Jepson-Innes. 1994. Aposematic coloration in Dactylotum variegatum (Orthoptera: Acrididae): support from vertebrate feeding trials. Southwestern Naturalist 39:21-25.

Onsager, J.A., and J.E. Henry. 1978. A method for estimating the density of rangeland grasshoppers (Orthoptera: Acrididae) in experimental plots. Acrida 6:231237.

PARKER, M.A. 1982. Thermoregulation by diurnal movement in the barberpole grasshopper (Dactylotum bicolor). American Midland Naturalist 107:228-237.
PfaDT, R.E. 1982. Density and diversity of grasshoppers (Orthoptera: Acrididae) in an outbreak on Arizona rangeland. Environmental Entomology 11:690-694.

Quinn, M.A., AND D.D. WALgEnBaCH. 1990. Influence of grazing history on the community structure of grasshoppers of a mixed-grass prairie. Environmental Entomology 19:1756-1766.

Redfearn, A., And S.L. Pimm. 1988. Population variability and polyphagy in herbivorous insect communities. Ecological Monographs 58:39-55.

Roberts, H.R. 1947. Revision of the Mexican Melanoplini (Orthoptera: Acrididae: Cyrtacanthacridinae). Proceedings of Academy of Natural Science of Philadelphia 49:201-230.

SAMWAYS, M.J. 1994. Insect conservation biology. Chapman and Hall, London.

SAvory, A. 1999. Holistic resource management. Island Press, Washington, DC.

SouthwoOD, T.R.E. 1978. Ecological methods with particular reference to the study of insect populations. Chapman and Hall, New York.

SYSTAT. 1997. SYSTAT 7.0 for Windows. SPSS, Inc., Chicago, IL.

VON ENDE, C.N. 1993. Repeated-measures analysis: growth and other time-dependent measures. Pages 113-137 in S.M. Scheiner and J. Gurevitch, editors, Design and analysis of ecological experiments. Chapman and Hall, New York.

Weatherhead, P.J., And K.L. Teather. 1991. Are skewed fledgling sex ratios in sexually dimorphic birds adaptive? American Naturalist 138:1159-1172.

Welch, J.L., R. RedaK, and B.C. Kondratieff. 1991. Effect of cattle grazing on the density and species of grasshoppers (Orthoptera: Acrididae) of the Central Plains Experimental Range, Colorado: a reassessment after two decades. Journal of the Kansas Entomological Society 64:337-343.

Whitford, W.G., G.S. Forbes, and G.I. KerLey. 1995. Diversity, spatial variability, and functional roles of invertebrates in desert grassland ecosystems. Pages 152-195 in M.P. McClaran and T.R. Van Devender, editors, The desert grassland. University of Arizona Press, Tucson.

Whitman, D.W. 1990. Grasshopper chemical communication. Pages 357-391 in R.F. Chapman and A. Joern, editors, Biology of grasshoppers. John Wiley and Sons, New York.

WiEnS, J.A. 2001. Understanding the problem of scale in experimental ecology. Pages 62-88 in R.H. Gardner, W.M. Kemp, V.S. Kennedy, and J.E. Petersen, editors, Scaling relations in experimental ecology. Columbia University Press, New York.

WILson, E.O. 1987. The little things that run the world (the importance and conservation of invertebrates). Conservation Biology 1:344-346.

Received 15 November 2004 Accepted 7 June 2005 